\title{
How Voters Assess Elite-Educated Politicians: A Survey Experiment ${ }^{1}$
}

\author{
Thomas Gift \\ Department of Political Science \\ University College London \\ t.gift@ucl.ac.uk \\ Carlos X. Lastra-Anadón \\ Freeman Spogli Institute \\ Stanford University \\ $\&$ \\ IE School of Global and Public Affairs \\ clastra@faculty.ie.edu
}

\begin{abstract}
Are politicians with elite backgrounds more electable? In this article, we test whether being an elite is a net positive or negative in running for public office via an original survey experiment that manipulates one of the most salient indicators of eliteness in American life: university education. We find that liberals, but not conservatives, perceive politicians who attended elite schools to be more competent. Meanwhile, conservatives, but not liberals, perceive politicians who attended elite schools to be less relatable. On average, citizens are mildly, but not significantly, less inclined to vote for elite-educated politicians. By embedding treatments in our survey for whether politicians came from advantaged or disadvantaged upbringings, we also confirm that our results do not entirely reflect generic attitudes toward economically privileged candidates.
\end{abstract}

Keywords: elites, universities, education, candidates, politicians, elections, experiment

\footnotetext{
${ }^{1}$ The authors are grateful to Mark Hill at the Harvard Digital Lab for the Social Sciences for his help in executing the survey experiment. They also thank Jeanne Burke, Ryan Enos, Leslie Finger, Daniel Hamlin, Daniel Krcmaric, Jonathan Monten, Paul E. Peterson, Beth Schueler, and Marty West for useful feedback and suggestions. The authors are indebted to the Program on Education Policy and Governance (PEPG) at the Harvard Kennedy School for providing institutional support during the writing of this paper.
} 
Elites are - and always have been - disproportionately represented in the halls of American power. From Congress to the White House and beyond, elites dominate U.S. elections. But do voters actually want it that way? Although eliteness in America can be defined in myriad ways - in terms of class, wealth, family, and so forth - an important marker of eliteness is educational pedigree. In this article, we explore whether an education at an elite university - a salient badge of eliteness in U.S. society - is a net positive or negative for politicians in campaigns.

There is no doubt that a small number of elite universities serve as the prime breeding grounds for American power brokers. Harvard, for example, has produced eight presidents, and Yale, five. Today, more than 40 Harvard graduates count themselves among the 115 th U.S. Congress (Cheng, Gorlinski, and Wang, 2016). The 2016 race for the White House again ended in Ivy League versus Ivy League, with Penn's Wharton School (Donald Trump) defeating Yale Law School (Hillary Clinton). Judging by their successes, it is tempting to conclude that electorates prefer elite-educated politicians.

Yet other factors could also explain why elite-educated politicians are disproportionately represented in U.S. government. For one thing, graduates of elite schools could simply be more likely to run for public office. The ambitious culture of elite universities might also attract students looking to enter politics - or convince those enrolled to do so. Furthermore, alumni of elite schools may enjoy access to high-powered networks that can fast-track their political careers. Finally, elite-educated politicians could possess more of other qualities - like being smart or charismatic - that appeal to voters. 
Even politicians themselves seem conflicted on whether an elite education helps in campaigns. Republican Senator Tom Cotton, for example, once touted his Harvard degree to the point that an opponent accused him of "us[ing] Harvard to further his political career" (Quoted in Glueck, 2014). On the other hand are politicians who distance themselves from Ivy League monikers - or use them to smear their competition. Christine O'Donnell, a former Tea Party candidate for the U.S. Senate, once began a campaign ad by declaring, "I didn't go to Yale...I'm you" (Quoted in Adams, 2010).

What is clear is that the alma maters of politicians are well-advertised. Between June 6, 2015 and January 11, 2018, for example, President Trump referenced his Wharton credentials no fewer than 52 times (Graves, 2018). Moreover, Frank Bruni of the New York Times points out the difficulty of escaping the educational details of candidates with elite degrees. "If you...Google Ted Cruz," he says, "and you download ten profiles of Ted Cruz that are of a certain length, I guarantee you that nine or ten of them are going to tell you...that he went to Princeton, and then...Harvard for law school" (Bruni, 2015).

Is a degree from an elite university an asset (or a liability) for politicians? Does attending an elite university score political points with voters? We theorize that the answers to these questions depend simultaneously on the ideology of voters and the specific traits of a candidate that they are judging. Liberals and conservatives evaluate elite-educated politicians differently based on a distinct set of ideological priors that they hold toward the merits of elite schooling. Their opinions vary conditional on whether they are assessing the competence or relatability of candidates. 
With respect to competence, we posit that an elite education signals that a candidate is academically talented because of who gets admitted to elite universities and what they learn at these institutions. Conservatives, however, may de-prioritize - or even be suspicious of - this quality in evaluating how politicians fulfill their job responsibilities. Unlike liberals, conservatives often distrust experts and the role that intellectuals play in public life. As a consequence, liberals should view elite-educated politicians as more competent, whereas this may not be true of conservatives.

Regarding relatability, we claim that an elite education signals that a candidate is personally removed from everyday citizens, again because of who gets into elite universities and what they learn while there. Liberals, however, may not think that this makes politicians unable to connect with voters. Unlike conservatives, liberals might believe that the progressive ideals prevalent at elite universities promote empathy and social awareness among graduates. As a result, conservatives should see elite-educated politicians as less relatable, whereas this may not be true of liberals.

To test our theory, we conduct an original survey experiment with a national convenience sample in the United States. We randomly assign whether hypothetical politicians went to elite or non-elite universities and measure how respondents evaluate their competence, relatability, and ballot box appeal. ${ }^{2}$ Because attending an elite university likely correlates with other traits that may matter to voters - especially economic status - we also vary in some cases whether

\footnotetext{
${ }^{2}$ As discussed later, we also included a control treatment in which some respondents were randomly not provided any information on the educational background of a candidate.
} 
politicians were born to wealth or poverty to separate elite education effects from generic attitudes toward economic privilege. ${ }^{3}$

In line with our theory, we discover that liberals see elite-educated politicians as more competent, whereas conservatives see them as no more or no less competent. Meanwhile, conservatives see elite-educated politicians as less relatable, whereas liberals see them as no more or no less relatable. On net, respondents are mildly, but not significantly, less inclined to vote for elite-educated candidates. Although voters generally prefer poor over rich candidates, assumptions by voters about the economic privilege level of elite-educated candidates cannot entirely explain our results.

Overall, our study reveals the complex - and often competing - opinions that the U.S. electorate holds toward elites. It also adds to a rich literature on candidate experiments, which shows that voters frequently rely on informational shortcuts to assess politicians. Practically, our study offers insight into whether elite-educated politicians should highlight their educational backgrounds in campaigns. Although elite degrees do not make candidates any more (or less) electable overall, they may still help (or hurt) politicians with specific parts of their profile among certain voters.

\section{Eliteness, Education, and Candidate Likeability}

It is well-known that people use informational shortcuts. Reaching optimal decisions is often either too burdensome or impossible, so individuals simply aim for good enough choices (e.g., Simon, 1956; Tversky and Kahneman, 1974). An important application of this concept is in

\footnotetext{
${ }^{3}$ Elite university attendance could also vary with other traits, notably the partisanship of the candidate. See a later discussion on this point.
} 
politics, and specifically voting (e.g., Downs, 1957; Popkin, 1991). Information-gathering in elections is costly. Voters typically have neither the time nor inclination to research all relevant details on candidates. As a consequence, they search for signals that politicians would make good public officials.

An extensive literature utilizes this logic to explain why voters prefer certain politicians. ${ }^{4}$ Studies examine a variety of traits attached to politicians to estimate whether they boost or detract from electoral appeal. These include social class (e.g., Wuest and Pontusson, 2018), religion (e.g., Calfano and Djupe, 2009), occupation (e.g., McDermott, 2005), level of education (e.g., Campbell and Cowley, 2014), gender (e.g., Sanbonmatsu, 2002), race (e.g., Terkildsen, 1993), age (e.g., Sigelman and Sigelman, 1982), upbringing (e.g., Carnes and Sadin, 2015), and physical looks (e.g., Lenz and Lawson, 2011).

Much of the scholarship on candidate likeability is experimental, whereby researchers alter specific variables of interest while holding others constant. Studies assume that voters use informational shortcuts - for example, in candidate biographies - to evaluate politicians. Because observational studies do not allow for such a controlled manipulation, it is hard to ascertain otherwise whether a certain candidate trait drives voter support or whether that trait is merely collinear with other traits that matter to voters. Candidate experiments mitigate, if not fully eliminate, this challenge. ${ }^{5}$

\footnotetext{
${ }^{4}$ See Rapoport, Metcalf, and Hartman (1989) for a foundational discussion of how voters make inferences about politicians based on candidate characteristics.

${ }^{5}$ One limitation of candidate experiments, of course, is that they risk oversimplifying decisions by the public by moving away from actual choices at the ballot box to self-reported intentions under artificial conditions. In the real world, voter behavior reflects multifaceted assessments of politicians. Candidate experiments, by their nature, can only capture a relatively small set of characteristics attributed to a politician. In promising new developments, however, researchers have attempted to run experiments in an efficient way via conjoint analysis (e.g., Hainmueller, Hopkins, and Yamamoto, 2014).
} 
Despite the long list of studies on candidate likeability, one variable that remains underexplored is where politicians were educated. This is surprising given the significant attention paid to the alma maters of candidates in modern elections. High-profile examples exist of politicians using their educational experiences to make the case for being elected. By contrast, other politicians use the educational experiences of their opponents to critique them. Generally, these debates in the United States revolve around the eliteness of universities, with much fixation on the Ivy League.

Research has explored whether voters prefer politicians who attended higher education at all (Campbell and Cowley, 2014; Carnes and Lupu, 2016a). Today, however, few high office-holders lack a university degree. ${ }^{6}$ A small number of candidate experiments use type of university education (e.g., Ivy League, state university) as one of several factors to gauge voter support for politicians (Abrajano, Elmendorf, and Quinn, 2014; Hainmueller, Hopkins, and Yamamoto, 2014). Yet education is only a minor part of these analyses, with little (or no) theory about why it should influence voting.

Such experiments also have other limitations. Rather than using actual school names (e.g., Harvard), they only inform respondents about what classification of school a politician attended. This raises questions about the relevance of their taxonomy. Experiments also tell us little about how an elite education might affect different qualities of a candidate or why we might expect citizens to assess these qualities differently. They also do not probe whether an elite education matters in itself, or if voters merely view it as a proxy for other traits, such as economic privilege.

\footnotetext{
${ }^{6}$ According to recent data, 100 percent of U.S. senators possess a university diploma, while 95 percent of U.S. House members do (Bump, 2017).
} 
A non-experimental, 2016 survey by the Pew Research Center did ask respondents whether they would be more likely to support a presidential hopeful who attended "a prestigious university, such as Harvard or Yale." ${ }^{77}$ Data reveal that Democrats reacted more positively to elite-educated politicians than Republicans. Such evidence, however, is removed from the real-life scenario in which voters must pick up on university cues without explicitly being asked. Again, the study provides no theoretical logic for why the results might have turned out as they did.

Understanding how voters assess elite-educated politicians is important on its own. But it also speaks to broader questions about the role of elites in public life and how they influence policy. On the one hand, some evidence suggests that elites may be better at governing, particularly when eliteness is a function of education (e.g., Besley, Montalvo, and Reynal-Querol, 2011). ${ }^{8}$ On the other hand, an overrepresentation of elite public officials could yield inegalitarian outcomes (e.g., Carnes, 2012; Griffin and Anewalt-Remsburg, 2013; Minta and Sinclair-Chapman, 2013).

Regardless of how citizens perceive elite-educated politicians, attending an Ivy League or other top university is a powerful emblem of eliteness in the United States. There is good reason to think that voters use this trait - consciously or not - to evaluate politicians. In the following section, we theorize how and why the educational backgrounds of candidates matter, with particular attention to the eliteness of their alma maters. We claim that how elite-educated politicians are perceived depends both on the ideology of voters and the specific characteristics that they evaluate.

\footnotetext{
${ }^{7}$ http://www.pewforum.org/2016/01/27/religion-and-other-candidate-traits/

${ }^{8}$ However, see Carnes and Lupu (2016b) for an alternative perspective.
} 


\section{Theory}

We build on the convention that elections in most advanced democracies, including the United States, are highly personalized (e.g., McAllister, 2007; Wattenberg, 1991). Rather than political machines and party bosses dictating electoral choices, voters look to the personal characteristics of politicians in deciding for whom they will cast a ballot. At the same time, how voters assess the personal traits of candidates depends on their own personal attributes. Personalization in elections thus occurs along two dimensions: among citizens and among politicians (Caprara et al., 2006).

Among citizens, evidence shows that the ideals, attitudes, and beliefs of voters are central to ballot box decisions. Because of the salience of the left-right divide in reflecting these values, we identify ideology as the main gradient along which voters will differentially assess elite- and non-elite-educated politicians. This intuition builds on research showing that whether one is liberal or conservative is a prime force behind how people interpret social hierarchies (e.g., Duckitt and Sibley, 2010; Jost, Federico, and Napier, 2009; Jost et al., 2003; Rathbun, 2007) and judge candidate traits (e.g., Goren, 2007; Laustsen, 2017).

Among politicians, evidence shows that the ability to resonate with voters is an essential predictor of electability. Because citizens want representatives who can both accomplish tasks and understand their needs, we contend that voters will judge candidates based on these capacities. Although the precise terms used to describe these abilities vary in the literature, we broadly refer to them as competence and relatability. Qualities bearing on competence and 
relatability figure prominently in candidate evaluations (e.g., Bittner, 2011; Laustsen and Bor, 2017; Ohr and Oscarsson, 2013). ${ }^{9}$

Below, we theorize how liberals and conservatives should judge the competence and relatability of politicians based on whether candidates attended elite or non-elite universities. We first discuss the competence of politicians, which speaks to their skills and expertise. We assert that attending an elite university should signal that a politician is academically talented. Unlike liberals, however, conservatives may not think that this attribute makes a politician more competent. This is because conservatives may question intellectuals and the merits of expert-driven policy.

We then turn to the relatability of politicians, which refers to their disposition and empathy. We claim that attending an elite university should signal that politicians are personally removed from everyday citizens insofar as their backgrounds and experiences diverge from the norm. Unlike conservatives, however, liberals may not believe that this makes a politician unrelatable. This is because liberals might think that the progressive ideals prevalent at elite universities - such as multiculturalism, diversity, and tolerance - confer a degree of social awareness. $^{10}$

\section{Competence}

\footnotetext{
${ }^{9}$ For an excellent review, see McGraw (2011).

${ }^{10}$ Our theory applies to how elite universities are seen today and in the last several decades. Before the 1960 s or so, elite universities did not necessarily carry the reputation of being exclusively bastions of the intellectual elite. Instead, their campuses were mostly filled with the offspring of wealthy aristocrats. Nor did elite universities carry the reputation of being paragons of progressive ideals. Rather, they were generally traditional institutions.
} 
All voters, regardless of their ideology, should recognize elite-educated politicians as academically talented. This is both because of who gets into elite universities and what they learn at these institutions. In terms of who gets into elite universities, admissions are fiercely competitive. Elite schools fill their classes with diverse hyper-achievers. To gain entry, students generally need nearly perfect SAT scores and superior grades in high school. So long as voters trust this vetting process, they can be assured that a politician who cleared the admissions bar is intelligent.

Voters should also think that elite-educated politicians are academically talented because of what students learn at elite universities. America's best institutions of higher learning are renowned for top-flight academics. Nobel laureates and internationally-recognized researchers teach at elite universities. Elite universities are also known for their depth and breadth of course curricula, for their demanding intellectual environments, and for their unparalleled resources. Voters ought to perceive elite-educated politicians as more knowledgeable because they studied in these settings.

Although attending an elite university should equate with academic talent, conservatives may dismiss this quality. The least charitable explanation is that conservatives are actually hostile to intellectuals. Several analyses, for example, find an anti-intellectual strain afflicting parts of the political right (e.g., Laverghetta, Stewart, and Weinstein, 2007; Shogan, 2007). One writer even laments a "conservative intellectual crisis" in the United States (Brooks, 2016). Data also suggest that, in recent years, anti-intellectualism has peaked among American conservatives (Gauchat, 2012; Motta, 2018). 
Anti-intellectualism may manifest in hostility to science, reason, and Enlightenment values. In this vein, the conservative wing in America is often criticized for adopting anti-intellectual policy stances such as climate change denial or the teaching of creationism in public schools (e.g., Mooney, 2005; Steel and Wolters, 2018). One critic, for example, talks of a "dumbing down of conservatism" (Lewis, 2016, n.p.). To the extent that the Ivy League epitomizes intellectual culture, a disdain for the cognoscenti could lead conservatives to deride the merits of elite schooling.

A more charitable interpretation of why conservatives may not see academically talented politicians as more competent is that they discount the capacity of experts to formulate policy (e.g., Sowell, 2009). According to one analysis, for instance, "The belief that the government should base its policy on neutral expertise dates back to the Progressive Era. The conservative movement has always recoiled at this model" (Chait, 2018). Instead, conservatives may be more apt to prioritize thinking through problems in a "common sense" way by relying on pragmatic or free-market principles (Boot, 2016).

This point may be especially salient to the extent that conservatives question the content and information taught at elite universities. For example, conservatives might perceive that biased curricula cause experts to rely too heavily on ostensible "facts" that they see as dubious, ideologically-infused, or simply incorrect. It would be difficult, for example, to find many economists at Ivy League universities who advocate "supply-side" over Keynesian economics. Yet the former models are more consistent with standard conservative orthodoxy about how the economy works. 
The liberal response to experts, by comparison, is generally different. Former President Barack Obama, for example, once showed his contempt for Republicans who he believed rejected the merits of expertise in policymaking: "It's like these guys take pride in being ignorant...they should go talk to some...experts and actually make a difference" (Quoted in New York Magazine, 2008). Recent polling data also reveal that Democrats are more likely than Republicans to rate intelligence as a "very important" quality in a president. ${ }^{11}$ In this way, liberals should see elite-educated politicians as more competent.

Based on this discussion, our first hypothesis is:

H1: Liberals will perceive elite-educated politicians as more competent than non-elite-educated politicians, whereas this may not be the case for conservatives.

\section{Relatability}

All voters, irrespective of their ideology, should view elite-educated politicians as personally removed from everyday Americans. This is again due both to who gets into elite universities and what they learn while there. Regarding who gets into elite universities, many students who attend Ivy League institutions have been socialized in exclusive environments such as private or elite suburban public schools - from an early age. This may signal to voters that elite-educated politicians possess certain breeding, tastes, and mores that diverge from those of average Americans.

${ }^{11}$ See YouGov Poll. July 10-13, 2014. http://cdn.yougov.com/cumulus_uploads/document/80cc49m8yu/tabs_OPI_intelligence_20140714.pdf Democrats were 8 percentage points more likely than Republicans to rate being intelligent as a "[v]ery important" quality in a president (84 vs. 76 percent) (page 9). 
Voters might also think that elite-educated politicians are personally removed from society because of what students learn at elite universities. One stereotype could be that, inside the classroom, faculty reinforce feelings of intellectual superiority. Another could be that, outside the classroom, students have difficulty staying grounded amid a lavish social scene. Whether it is final clubs at Harvard, secret societies at Yale, or eating clubs at Princeton, elite universities put students in contact with high culture. This may fuel the perception that elite-educated politicians are not down-to-earth.

Both liberals and conservatives should agree that elite-educated politicians are personally removed from everyday citizens. Yet even if conservatives think that this makes them unrelatable, liberals may not fully agree, as there are countervailing forces at work. Because of their worldviews, liberals may believe that the dominant values at elite universities - such as multiculturalism, diversity, and tolerance - grant social awareness to students. From their perspective, exposure to such principles might compensate for the limited contact that students have with everyday Americans.

Although most U.S. universities lean left politically, ${ }^{12}$ elite schools do so especially. At Princeton, for example, Democratic faculty outnumber Republicans 30 to 1 in certain disciplines. At Brown, that ratio is 60 to 1 (Langbert, Quain, and Klein, 2016). Former New York City mayor Michael Bloomberg has complained that "on many college campuses, it is liberals trying to repress conservative ideas, even as conservative faculty members are at risk of becoming an endangered species. And perhaps nowhere is that more true than...in the Ivy League" (Quoted in Strauss, 2014).

\footnotetext{
12 Overwhelming evidence indicates that university faculty in the United States tend to lean to the left politically (Gross 2013; Gross and Simmons 2014).
} 
Consistent with their progressive views, faculty at elite universities may be more apt to expose students to identity-based and socially-conscious curricula (e.g., Berkowitz, 2017). They may offer more classes - and place more emphasis - on topics such as gender, race, intersectionality, and so on. Liberals might look upon this favorably to the extent that it provides students a fuller understanding of the challenges faced by diverse groups in America. They may also sense that elite-educated politicians are cognizant of social problems, even if they have limited exposure to them firsthand.

Students at elite universities are frequently depicted as staunch (and even radical) advocates for progressive causes such as multiculturalism, environmentalism, and social justice. Recently, Ivy League students have become embroiled in high-profile battles against alleged cultural appropriation (leading to protests over "insensitive" Halloween costumes at Yale) (Stack, 2015) and non-inclusiveness (prompting calls to change Harvard's alma mater song due to references to a particular religious faith) (Karr, 2017). Liberals may appreciate that students at elite universities take these stands.

For conservatives, by contrast, the progressive sensibilities of elite universities - on issues ranging from LGBTQ+ rights to affirmative action - may spark negative reactions (e.g., Maranto, Redding, and Hess, 2009). In the words of two Harvard law professors, "the distinctive progressive ideology of elite universities is relentlessly critical of, to the point of being intolerant of, traditions and moral values widely seen as legitimate in the outside world" (Goldsmith and Vermeule 2017). In this way, conservatives should see elite-educated politicians as distant from their lifestyles and thus less relatable.

Based on this discussion, our second hypothesis is: 
H2: Conservatives will perceive elite-educated politicians as less relatable than non-elite-educated politicians, whereas this may not be the case for liberals.

\section{Ballot Box Appeal}

When it comes to ballot box appeal, we do not make any predictions about the relative propensity of liberals and conservatives to vote for elite-educated politicians. Although both competence and relatability are likely to figure centrally in how citizens evaluate candidates, voters of different ideologies may judge and attach different relative importance to each of these qualities at the ballot box. For example, even if a voter assesses a politician as more competent, this may (or may not) translate into him or her supporting that candidate at the ballot box. That decision depends on the simultaneous assessment of both the perceived competence and relatability of the candidate and how much weight the voter assigns to each quality. In the same way, even if a voter assesses a politician as less relatable, this may (or may not) translate into him or her rejecting that candidate at the ballot box. There is considerable debate as to how citizens weigh different attributes of candidates in voting decisions. An empirical resolution of that debate is a significant challenge for the political behavior literature. In our analysis, we provide results of the ballot box appeal of elite-educated politicians to document the consequences of our primes on the likely voting behavior of liberals and conservatives.

\section{Methodology}

To test our hypotheses, we undertook a candidate experiment in which respondents were asked to read biographical sketches of fictitious politicians and then assess those candidates on 
their competence, relatability, and ballot box appeal. By randomly varying where politicians attended university, we can deduce with greater confidence whether voters prefer candidates who attended elite schools.

-Data

We ran our experiment online via the Harvard Digital Lab for the Social Sciences during May 12-June 30, 2017. DLABSS is a well-established survey platform that asks volunteers to respond to questionnaires on pertinent social science issues. ${ }^{13}$ When we fielded our survey, the DLABSS pool consisted of approximately 6,000 volunteers. Of this number, 745 people $18+$ years of age actually filled out our survey. We confined our analysis to the 658 who self-declared U.S. residency and responded to at least one of the dependent variable questions. Because respondents were asked to evaluate two fictitious candidates, we have 1,316 observations. Overall, the DLABSS pool is more representative of the U.S. population than many other convenience samples (e.g., college students). ${ }^{14}$ It is similar to a typical MTurk sample, although more representative on certain dimensions. ${ }^{15}$ When compared to the Current Population Survey and the American National Election Studies, DLABSS participants are more educated, earn less income, and are more likely to vote. ${ }^{16}$ Researchers have utilized DLABSS to successfully

\footnotetext{
${ }^{13}$ See Enos, Hill, and Strange (2017) for an overview of DLABSS and its mission. See Krupnikov and Levine (2014) for analysis of the merits and generalizability of certain non-nationally representative samples. For other work using DLABSS data, see Carney and Enos (2017).

${ }^{14}$ Appendix Table A1 summarizes the sample of U.S. residents who both took part in our survey and who answered all of the dependent variable questions.

${ }^{15}$ MTurk has been widely used in the experimental political science literature. See, for instance, Huber, Hill, and Lenz (2012) and the discussion therein.

${ }^{16}$ DLABSS participants have about two more years of education than participants in CPS and ANES, earn about $\$ 12,000-\$ 14,000$ less, and were about 10 to 18 percentage points more likely to vote in the 2008 election. See Table 1 on page 14 of Enos, Hill, and Strange (2017).
} 
replicate 15 social science experiments, which employed major platforms such as the nationally-representative General Social Survey. ${ }^{17}$

-Survey Design

For our survey, we began by creating descriptions of two similar politicians running for governor. The descriptions contained basic information that candidates would be likely to feature in a short biography, with nothing extraneous or unusual. We assigned to the candidates male names, as well as generic information relating to age, former careers/local government service, volunteer/charitable activities, marital status, and family composition. ${ }^{18}$ We then randomly introduced into the biographies whether a politician had attended an elite or non-elite university. We also included a control in which some respondents randomly received no information on the educational background of a candidate. Because it is unclear what respondents assume in this scenario, we do not make any predictions about how voters react here. Nonetheless, results may provide some indication as to the assumptions that voters make absent educational information.

-Selecting Elite and Non-Elite Schools

\footnotetext{
${ }^{17}$ Enos, Hill, and Strange (2017). This performance might be explained in part by the use of volunteer respondents, who participate without guaranteed compensation. Because respondents are intrinsically motivated, participants may be more careful about how they answer questions. See, for example, Mason and Watts (2010).

${ }^{18}$ We omitted a partisan cue from the biographies - namely, whether the candidate is a Democrat or a Republican - because, in limited information settings, we would expect a party label to absorb nearly all the variation in assessments among liberal and conservative respondents. In our survey, we did ask respondents to guess whether the candidate was a Democrat, Republican, or Other. Response rates, however, were unusually low (43 percent for those who took the survey, compared to the 87-88 percent range for questions on perceived competence, perceived relatability, and ballot box appeal). This likely reflects a lack of confidence on behalf of respondents in answering this question.
} 
In selecting our university treatments, we abstract out much of the variation in eliteness that exists in American higher education to focus only on truly "elite" versus "good" schools. Although what constitutes a truly elite school is not completely objective, it seems reasonable that a few universities are members of this club, even if one could make the case that others are equally deserving. For elite schools, we varied the treatment between Harvard, Yale, and Princeton. These three Ivy League universities are perennially rated at or near the top of the U.S. News \& World Report college rankings. They are well-known, have historical cache, and are synonymous with exclusivity and prestige. In short, Harvard, Yale, and Princeton project the qualities that even a casual observer would associate with the term elite. ${ }^{19}$ To identify good, but non-elite, institutions, we began with the 50th rated schools in the 2017 U.S. News and World Report's ranking of national universities and worked "upwards" to better-rated schools until we found three schools that fit certain criteria. We focused on national universities - which also include Harvard, Yale, and Princeton - because, in terms of their sizes, institutional missions, and degree awards, the schools should be similar. We excluded: public institutions (to avoid loyalties to state flagship universities); schools with sectarian affiliations (to obviate religious confounders); universities not in the northeast (to rule out clear geographic differences); and tech schools (to concentrate on institutions with generalist curricula). The first three universities suitable for comparison were: Lehigh University (T-44), Northeastern University (T-39), and

\footnotetext{
${ }^{19}$ Highly rated schools, of course, are not always the best known. Several top liberal arts colleges including Amherst, Swarthmore, and Williams - doubtlessly rival many of their better-known peers when it comes to academic rigor, selectivity, and esteem within the academy. Yet their more modest profiles make it less likely that the public will know them. Consequently, concentrating on larger schools with popular brand recognition seems reasonable given that politicians would have less reason to highlight or downplay degrees from smaller schools if voters are unaware of them.
} 
Boston University (T-39). ${ }^{20}$ We selected three elite and three non-elite schools to minimize the chances that a single university would drive our results due to an idiosyncratic reputation. In our main analysis, we group all elite schools as one treatment and all non-elite schools as another.

\section{-Separating out Generic Economic Eliteness}

As mentioned earlier, a potential confounder in our experiment may be that attending an elite university generically proxies economic eliteness. Because students at elite schools hail overwhelmingly from privileged backgrounds, ${ }^{21}$ an elite education may not be important in itself, but simply reflect general views toward economic elites. To address this concern, we supplement our main treatments with additional ones that explicitly account for economic privilege. Our privileged ("silver spoon") treatment is being "[b]orn the son of a wealthy businessman." Our less privileged ("plastic spoon") treatment is being "[b]orn the son of a poor farmer." By assigning these markers randomly to some of the candidates, we can guard against the possibility that assumptions about economic privilege bias our analysis. If our findings still hold even when respondents know that a politician comes from a given level of economic privilege, it improves confidence in our results.

\section{-Summary of the Treatments}

The text used in our primes is depicted as follows:

\section{Candidate A}

\footnotetext{
${ }^{20}$ It is worth stressing that the non-elite schools we chose are clearly of excellent quality. Choosing good, as opposed to lower-quality, schools - or ones with virtually no brand name - increases the chances that we are capturing an elite school effect. Comparing elite to good schools like Lehigh, Northeastern, and BU should present a more difficult test for us.

${ }^{21}$ Chetty et al. (2017, page 2), for example, find that "[a]mong 'Ivy-Plus' colleges (the eight Ivy League colleges, University of Chicago, Stanford, MIT, and Duke), more students come from families in the top $1 \%$ of the income distribution (14.5\%) than the bottom half of the income distribution (13.5\%)."
} 
Chuck Smith is a 57-year old former business manager who is running for governor. [Spoon treatment] [Education treatment] After working for a large company, he entered public service, where he served in several capacities in local government, including on the town council. Now, Smith spends much of his free time volunteering for non-profits. Smith is married with 3 children.

\section{Candidate B}

Mark Soskice, previously an economic consultant, is 54 years old and running for governor. [Spoon treatment] [Education treatment] Following his career at a big corporation, he shifted to public service, where he assumed multiple roles in local government, including on the school board. Today, Soskice can often be found supporting charitable causes. Soskice has a wife and 4 kids.

\section{Education treatments}

-Elite: "[H/h]e received his degree from [Harvard / Yale / Princeton] University."

-Non-elite: "[H/h] e received his degree from [Lehigh / Northeastern / Boston] University."

-No information: “" (Blank)

\section{Spoon treatments}

-Silver: "Born the son of a wealthy businessman,"

-Plastic: "Born the son of a poor farmer,"

-No information: “" (Blank)

Respondents read biographies for Candidates A and B in succession so as to obtain two observations for each respondent. After reading the biography of the first candidate, the respondent answered questions about him. Next, after reading the biography of the second candidate, the respondent answered questions about him. The order of the biographies was randomized, however, to minimize systematic cross-contamination. In each case, the candidate was randomly assigned one of the following markers:

T0) No school \& No spoon mentioned (control)

T1) Elite school \& No spoon mentioned

T2) Non-elite school \& No spoon mentioned

T3) Elite school \& Silver spoon

T4) Elite school \& Plastic spoon

T5) Non-elite school \& Silver spoon

T6) Non-elite school \& Plastic spoon

-Key Response Variables 
After being presented with the biographies, we asked respondents to rate each candidate on several criteria using a 1-7 Likert scale of agreement (from $1=$ "Strongly disagree" to $7=$ "Strongly agree"). Respondents were asked to say how much they concurred with a given statement about a candidate designed to shed light on his: 1) perceived competence; 2) perceived relatability; and 3) ballot box appeal. For competence, the statement that respondents assessed was simple: "This candidate would be competent in office." Relatability, however, is likely more multifaceted. As such, we constructed a mean index based on the average values of the assessments for the following statements: "This candidate would fight for people like me"; "This candidate would be fun to spend time with socially (e.g. have coffee or grab a beer with)"; and "This candidate would understand my concerns."22 Lastly, for ballot box appeal, the statement that respondents evaluated was again straightforward: "This candidate is someone I would vote for." 23

\section{Empirics}

We estimate variations of the following model:

$$
\text { (1) } Y_{i}=\alpha+\beta \text { Elite }_{i}+\gamma \text { No info } o_{i}+X_{i}+\varepsilon_{i}
$$

where $Y$ is one of three dependent variables (denoting perceived competence, perceived relatability, and ballot box appeal); Elite and No info are (mutually exclusive, randomized) school treatments (Non-elite is the reference category); and $X$ is a vector of individual-level

\footnotetext{
${ }^{22}$ For responses where at least one of the three components of the relatability index is missing, we drop the observation from our models. This reduces our sample by five responses.

${ }^{23}$ Appendix Table A2 shows the correlations between our three dependent variables - perceived competence, perceived relatability, and ballot box appeal. Notable is that the relationship between perceived competence and perceived relatability is 37 percent short of perfect collinearity. This suggests that the variables do not move fully in tandem and in fact capture different dimensions of candidate appeal.
} 
demographic controls for respondent $i$, as well as a candidate dummy. ${ }^{24}$ We assume the DV to be linear in our core models.

\section{Results and Discussion}

Before examining our hypotheses by ideological group, we first evaluate average treatment effects for where politicians attended university. Model 1 of Table 1 shows results with perceived competence as the DV. The coefficient on the Elite treatment $(\beta=.11)$ is positive, but not statistically significant. Model 2 of Table 1 provides results with perceived relatability as the DV. The coefficient on the Elite treatment $(\beta=-.09)$ is negative, though again not statistically significant. Model 3 of Table 1 depicts results with ballot box appeal as the DV. We find a negative, though again not statistically significant, effect of the Elite treatment $(\beta=-.06)$.

Overall, our regressions indicate that, on average, voters neither prefer nor disprefer elite-educated politicians when assessing their perceived competence, perceived relatability, and ballot box appeal.

[Table 1 here]

Competence Results: Turning now to our hypotheses, we start by investigating whether liberals deem elite-educated politicians to be more competent than conservatives do. To unpack effects by ideology, we introduce a binary variable, Conservative, that denotes self-identified

\footnotetext{
${ }^{24}$ We include controls for respondent gender (female), race (non-white), ethnicity (Hispanic), age, education (college graduate), economic status (annual income), and party allegiance (Republican and Other). In the case of missing data for control variables (except party allegiance), in order to ensure we use all available non-missing information from every observation, we use the simple method of imputing a value of zero and then including a missing variable indicator (Cohen and Cohen, 1975). When we use ideology as a mediating variable, we do not impute missing values.
} 
conservative respondents. ${ }^{25} \mathrm{We}$ interact the Conservative variable with variables for the Elite and No info treatments (making the omitted category liberals assigned to the Non-elite treatment). Our model is expressed as:

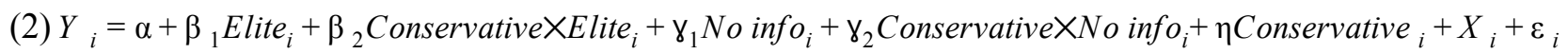

Model 1 of Table 2 presents these results. As expected, controlling for their baseline levels of support for candidates, liberals believe that elite-educated politicians are more competent than politicians with non-elite educations $\left(\beta_{1}=.22\right)$, and this effect is statistically significant. There is no statistically significant evidence, however, that conservatives see elite-educated politicians as any more or less competent than non-elite-educated politicians $\left(\beta_{1}+\beta_{2}=-.03\right) .{ }^{26}$ As illustrated by Figure 1, among liberals (indicated by the dashed line), the average competence score of elite-educated politicians (at average levels of the covariates) is 5.27, compared to just 5.06 for non-elite-educated politicians. Meanwhile, for conservatives (indicated by the solid line), the average competence scores of elite- and non-elite-educated politicians are 4.92 and 4.89, respectively. These findings substantiate that liberals perceive elite-educated politicians as more competent than non-elite-educated politicians, whereas conservatives do not. ${ }^{27}$

[Figure 1 here]

\footnotetext{
${ }^{25}$ The question about ideology is phrased as follows: "In politics, do you consider yourself liberal or conservative?" This is a forced binary choice, although respondents can skip the question. 10.3 percent of our respondents did so and thus were dropped from the analyses where ideology is a moderator.

${ }^{26}$ Although our theory makes no explicit predictions about it, when comparing ideological groups to one another, we do not find that liberals prefer elite-educated politicians significantly more than conservatives $\left(\beta_{2}=-.25\right)$.

${ }^{27}$ These are the values of the DVs for each group at the mean values of the covariates. They differ slightly from the ones that can be read directly from Table 2, as the covariates are not shown.
} 
Relatability Results: We next probe whether conservatives find elite-educated politicians to be less relatable than liberals do. To do so, we replicate Model 1 of Table 2, except we change the DV to gauge perceived relatability. Model 2 of Table 2 shows these results. In line with our theory, controlling for their baseline scores given to politicians, conservatives find candidates who attended elite institutions to be less relatable than those who attended non-elite ones $\left(\beta_{1}+\beta_{2}=\right.$ -.26), and this effect is statistically significant. ${ }^{28}$ There is no statistically significant evidence, however, that liberals find politicians educated at elite universities any more or less relatable than their peers educated at non-elite schools $\left(\beta_{1}=.03\right)$. As depicted in Figure 2, among conservatives, the average relatability score of elite-educated politicians (at average levels of the covariates) is just 4.22, whereas it is 4.37 for non-elite-educated politicians. For liberals, the average relatability score of politicians with elite schooling is 4.36 , while it is 4.33 for politicians with non-elite schooling. These results confirm that conservatives see elite-educated politicians as less relatable than non-elite-educated politicians, but this is not true of liberals. ${ }^{29}$

[Figure 2 here]

Ballot Box Appeal Results: Lastly, we investigate how inclined liberals and conservatives are to vote for elite- versus non-elite-educated politicians. We estimate regressions similar to Models 1 and 2 of Table 2, except we employ ballot box appeal as our DV. Model 3 of Table 2 summarizes these results. Controlling for their baseline support levels for politicians, liberals are moderately more inclined to vote for elite- over non-elite-educated politicians $\left(\beta_{1}=.10\right)$, although this effect is not statistically significant. Conservatives, however, are less inclined to vote for

\footnotetext{
${ }^{28}$ When making express comparisons across ideological groups, liberals deem elite-educated politicians significantly more relatable than conservatives $\left(\beta_{2}=-.28\right)$.

${ }^{29}$ Appendix Table A3 replicates Model 2 of Table 2, but also disaggregates our relatability index into its constituent parts. None of the constituent variables entirely drive our results on relatability.
} 
candidates who attended elite as opposed to non-elite universities $\left(\beta_{1}+\beta_{2}=-.29\right)$, and this effect is statistically significant. ${ }^{30}$ Figure 3 graphs these results. For conservatives, the average ballot box appeal score (at average levels of the covariates) is only 4.13 for elite-educated politicians, whereas it is 4.42 for politicians who attended non-elite institutions. For liberals, the average ballot box appeal scores for candidates with elite and non-elite educations are 4.53 and 4.43 , respectively. $^{31}$

[Figure 3 here]

[Table 2 here]

Guarding against a Generic Economic Privilege Effect: As a robustness check, we address the concern that voters simply interpret a degree from an elite university as a generic indicator of economic privilege. To ensure that education matters in and of itself, we test whether our results hold even when respondents are always told explicitly that a politician came from advantaged ("silver spoon") or disadvantaged ("plastic spoon") origins. To execute this test, we restrict our sample to respondents who received a "spoon" in addition to an education treatment to ensure that respondents do not make assumptions about these characteristics. Our regressions are similar to Models 1, 2, and 3 of Table 2, except they introduce a Silver spoon variable and interact it with Conservative and Elite, as well as with the interaction of both. Results are presented in Models 1 (perceived competence), 2 (perceived relatability), and 3 (ballot box appeal) of Table 3. Although both liberals and conservatives generally prefer plastic over silver spoon candidates

\footnotetext{
${ }^{30}$ When drawing direct contrasts across ideological groups, liberals are significantly more inclined to vote for elite-educated politicians than conservatives $\left(\beta_{2}=-.40\right)$.

${ }^{31}$ Although we make no predictions about it, Appendix Table A4 tests whether liberals and conservatives assess elite-educated politicians differently than those for whom no information on university attendance is supplied. For none of the outcome variables do we find statistically significant differences.
} 
on average, ${ }^{32}$ spoon type does not considerably alter the relative attitudes of liberals and conservatives toward elite- and non-elite-educated politicians. As seen in Figure 4a-c, within ideological groups, the slopes of the lines denoting evaluations of rich and poor candidates tend to be similar directionally. ${ }^{33}$ In general, they are either both positive or both negative, and their signs do not deviate substantially from our core results. This corroborates that assumptions about the economic privilege level of candidates do not entirely drive our findings. Even when liberals and conservatives know for sure that candidates come from privileged or unprivileged upbringings, their respective ratings of politicians remain fairly consistent.

[Figures 4a-c here]

[Table 3 here]

Additional Robustness Checks: In addition to confirming that assumptions about the economic privilege of candidates do not fully explain our findings, we conduct several additional robustness checks. One concern might be that a single school that comprises an elite- or non-elite treatment is responsible for our results. To test for this possibility, Appendix Tables A5 and A6 break down our results by each of the three elite (Harvard, Yale and Princeton) and non-elite (Lehigh, Northeastern, and BU) school treatments, respectively. There is no clear evidence that any one school completely drives our findings. Another concern is that our results are confounded by voters making inferences about the partisan affiliation of the candidates based on whether politicians attended elite or non-elite universities. A potential scenario is that a voter

\footnotetext{
${ }^{32}$ For all the outcome variables, liberals significantly prefer the plastic spoon candidates. Conservatives, however, only significantly prefer the plastic spoon candidates when assessing relatability.

${ }^{33}$ The only instance of results diverging from this pattern is that liberals deem silver spoon, elite-educated candidates as less relatable than silver spoon, non-elite-educated candidates, whereas they perceive plastic spoon, elite-educated candidates as more relatable than plastic spoon, non-elite-educated candidates. Neither effect, however, is statistically significant.
} 
sees that a politician attended Harvard, Yale, or Princeton and thus assumes that the candidate is a Democrat because Ivy League schools are disproportionately filled with students who self-declare as Democrats. In Table A7, we add a control variable that captures the respondent's guess of the partisan affiliation of the candidate to models mediated by respondent ideology in Table 2. If the impact of our treatments was through shifting the presumed partisanship of the candidate, adding that variable would weaken the treatment effects on perceived competence, perceived relatability, and ballot box appeal. This is not the case, however. ${ }^{34}$ Finally, we confirm that our core findings hold under alternative model specifications. In Table B1, we re-estimate regressions from Table 2 using linear models without individual-level demographic controls. In Table B2, we re-estimate regressions from Table 2 using ordered probit models with individual-level demographic controls. The results are substantively similar to our original estimations.

\section{Conclusion}

Elites are disproportionately represented in U.S. government. But do Americans want it that way? In an era where politicians and their strategists use every opportunity to gain an advantage over their competition, the choice to highlight that a politician attended an elite school could make or break a campaign. Yet surprisingly, we know little about this topic outside of

\footnotetext{
${ }^{34}$ Additionally, if respondents were simply assessing candidates based on whether they think they are Republicans or Democrats, we would expect evaluations of all the DVs - relatability, competence, and ballot box appeal - to run in the same direction. Conservatives would rate perceived Republicans highly across all dimensions, and the same for liberals with perceived Democrats. The fact that we actually find differential effects across the DVs lends credence to the idea that voters are not simply reacting to cues about whether the candidates are Democrats or Republicans.
} 
anecdotal examples, and politicians take contrasting approaches when it comes to emphasizing their elite educational credentials - or critiquing their opponents for attending elite schools.

In this article, we exploited an original survey experiment to probe whether Americans actually prefer politicians who attended elite universities. Results show that perceptions of elite-educated politicians depend both on the ideology of respondents and the particular traits of politicians being evaluated. Liberals, but not conservatives, view elite-educated politicians as more competent. Conservatives, but not liberals, view elite-educated politicians as less relatable. Attending an elite university mildly, but not significantly, reduces ballot box appeal among U.S. citizens as a whole.

Our experiment helps to overcome the main causal identification challenges linked to claims that voters are more or less attracted to politicians who attended elite universities. Specifically, it isolates variations in the eliteness of the alma maters of candidates that would normally be impossible in observational examinations. By introducing additional treatments for whether politicians came from economically advantaged or disadvantaged upbringings, we also alleviate the concern that our results are simply a byproduct of generic reactions to economic privilege.

Our study has implications for understanding U.S. attitudes toward elite rule. It shows that voters do not have a blanket set of views about whether elite-educated politicians are more competent or relatable. This also yields lessons for campaigns. Existing evidence indicates conflicting beliefs about whether a degree from an elite school is a net pro or con for politicians. Our findings cast doubt on whether an elite education improves the electoral appeal of candidates 
for any ideological group. It may even be detrimental for politicians courting conservative voters.

More theoretically, an active debate exists on what traits of politicians make them appealing to voters. As noted earlier, competence and relatability are two attributes discussed in the literature. With our experimental assignment of elite education, we show that citizen assessments of these traits vary independently. Moreover, we provide an example of a type of cue that can shift citizen perceptions of the traits of candidates, which in turn affect their ballot box appeal. While competence or relatability may not be directly observable, they can still inform candidate evaluations.

Going forward, one extension of our study might be to look at how the alma maters of politicians interact with other candidate attributes - such as partisanship, race, gender, and so on that affect voter appraisals. It would also be informative to replicate our study in a different setting, such as the United Kingdom, where Oxford produces a huge number of the country's politicians. Researchers might additionally explore whether other forms of eliteness - besides just university education - make candidates more or less likeable. These could include hobbies and other pursuits associated with elite lifestyles.

One particularly promising area for future research is to probe whether elite-educated politicians actually perform better once in office. With regard to competence, are elite-educated politicians more or less likely to achieve legislative and executive victories? With regard to relatability, are they more or less likely to push for laws and policies that represent the interests of average Americans? Identifying innovative empirical strategies to measure the real-world 
impact of politicians with elite schooling could yield important insight into their priorities and skill sets.

\section{References}

Aug. 6, 2008. Obama: 'It's Like These Guys Take Pride in Being Ignorant.' New York Magazine. Available at: nymag.com/daily/intelligencer/2008/08/links_6.html

Abrajano, Maris A., Christopher S. Elmendorf, and Kevin M. Quinn. 2014. Using Experiments to Estimate Geographic Variation in Racially Polarized Voting. Presented at Conference on Empirical Legal Studies. Berkeley.

Adams, Richard. Oct. 7, 2010. Christine O'Donnell: 'I didn't go to Yale' in Latest TV Ad. The Guardian. Available at:

https://www.theguardian.com/world/richard-adams-blog/2010/oct/07/christine-odonnell-delawar e-tv-ad-witch-yale

Berkowitz, Peter. Sept. 15, 2017. What's the Point of a Liberal Education? Don't Ask the Ivy League. Wall Street Journal. Available at:

https:/www.wsj.com/articles/whats-the-point-of-a-liberal-education-dont-ask-the-ivy-league-15 05513330

Besley, Timothy, Jose G. Montalvo, and Marta Reynal-Querol. 2011. Do Educated Leaders Matter? Economic Journal 121(554), 205-27.

Bittner, Amanda. 2011. Platform or Personality? The Role of Party Leaders in Elections. Oxford: Oxford University Press.

Boot, Max. July 31, 2016. How the 'Stupid Party' Created Donald Trump. New York Times. Available at:

https://www.nytimes.com/2016/08/01/opinion/how-the-stupid-party-created-donald-trump.html

Brooks, David. Oct. 28, 2016. The Conservative Intellectual Crisis. New York Times. Available at: https://www.nytimes.com/2016/10/28/opinion/the-conservative-intellectual-crisis.html

Bruni, Frank. April 11, 2015. Where You Go Is Not Who You'll Be: An Antidote to the College Admissions Mania. Speech. Family Action Network.

Bump. Philip. Feb. 2, 2017. Nearly Everyone in Congress has a College Degree. Most Americans Don't. Washington Post. Available at:

https:/www.washingtonpost.com/news/politics/wp/2017/02/02/nearly-everyone-in-congress-has -a-college-degree-most-americans-dont/?utm_term=.bdfd0c87a33d 
Calfano, Brian Robert and Paul A. Djupe. 2009. God Talk: Religious Cues and Electoral Support. Political Research Quarterly 62(2): 329-39.

Campbell, Rosie and Philip Cowley. 2014. What Voters Want: Reactions to Candidate Characteristics in a Survey Experiment. Political Studies 62(4): 745-765.

Caprara, Gian Vittorio, Shalom Schwartz, Cristina Capanna, Michele Vecchione, and Claudio Barbaranelli. 2006. Personality and Politics: Values, Traits, and Political Choice. Political Psychology 27(1): 1-28.

Carnes, Nicholas. 2012. Does the Numerical Underrepresentation of the Working Class in Congress Matter? Legislative Studies Quarterly 37(1): 5-34.

Carnes, Nicholas and Noam Lupu. 2016a. Do Voters Dislike Working-Class Candidates? Voter Biases and the Descriptive Underrepresentation of the Working Class. American Political Science Review 110(4): 832-844.

Carnes, Nicholas and Noam Lupu. 2016b. What Good Is a College Degree? Education and Leader Quality Reconsidered. Journal of Politics 78(1): 35-49.

Carnes, Nicholas and Meredith L. Sadin. 2015. The 'Mill Worker's Son' Heuristic: How Voters Perceive Politicians from Working-Class Families - and How They Really Behave in Office. Journal of Politics 77(1): 285-298.

Carney, Riley K. and Ryan D. Enos. 2017. Conservatism and Fairness in Contemporary Politics: Unpacking the Psychological Underpinnings of Modern Racism. Presented at the 2017 NYU CESS Experiments Conference.

Chait, Jonathan. Jan. 10, 2018. Why Republicans Love Dumb Presidents. New York Magazine. Available at:

nymag.com/daily/intelligencer/2018/01/why-conservatives-love-dumb-presidents.html

Cheng, Alice S., Lana M. Gorlinski, and William L. Wang. Nov. 9, 2016. More than 40 Harvard Alumni Win Seats in 115th Congress. Harvard Crimson. Available at:

http://www.thecrimson.com/article/2016/11/9/Harvard-alumni-win-congressional-seats/

Chetty, Raj, John N. Friedman, Emmanuel Saez, Nicholas Turner, and Danny Yagan. 2017. Mobility Report Cards: The Role of Colleges in Intergenerational Mobility. Working Paper. Available at: www.equality-of-opportunity.org/assets/documents/coll_mrc_paper.pdf

Cohen, Jacob, Patricia Cohen. 1975. Applied Multiple Regression Correlation Analysis for the Behavioral Sciences, New York: John Wiley.

Downs, Anthony. 1957. An Economic Theory of Democracy. New York: Harper \& Row. 
Duckitt, John and Chris G. Sibley. 2010. Personality, Ideology, Prejudice, and Politics: A Dual-Process Motivational Model. Personality and Politics 78(6): 1861-1894.

Enos, Ryan D., Mark Hill, and Austin M. Strange. 2017. Online Volunteer Laboratories for Social Science Research. Harvard University Working Paper.

Gauchat, Gordon. 2012. Politicization of Science in the Public Sphere: A Study of Public Trust in the United States, 1974 to 2010. American Sociological Review 77(2): 167-187.

Glueck, Katie. Oct. 14, 2014. Cotton, Pryor Get Rough in Last Debate. Politico. Available at: www.politico.com/story/2014/10/tom-cotton-mark-pryor-debate-arkansas-senate-2014-111893

Goldsmith, Jack and Adrian Vermeuele. Nov. 30, 2017. Elite Colleges are Making It Easy for Conservatives to Dislike Them. Washington Post. Available at: https://www.washingtonpost.com/opinions/elite-colleges-are-making-it-easy-for-conservatives-t o-dislike-them/2017/11/30/0d2ef31a-d52a-11e7-a986-d0a9770d9a3e_story.html?utm_term=.a7b d1 $835 \mathrm{e} 73 \mathrm{f}$

Goren, Paul. 2007. Character Weakness, Partisan Bias, and Presidential Evaluation: Modifications and Extensions. Political Behavior 29(3): 305-325.

Graves, Alex. Jan. 17, 2018. How Many Times has Trump Mentioned His Wharton Education? We Crunched the Numbers. Daily Pennsylvanian. Available at: www.thedp.com/article/2018/01/trump-penn-wharton-data-education-times-ivy-league-businessfinance-philadelphia-campaign

Griffin, John D. and Claudia Anewalt-Remsburg. 2013. Legislator Wealth and the Effort to Repeal the Estate Tax. American Politics Research 41(4): 599-622.

Gross, Neil. 2013. Why Are Professors Liberal and Why Do Conservatives Care? Cambridge, MA: Harvard University Press.

Gross, Neil and Solon Simmons, eds. 2014. Professors and Their Politics. Baltimore: Johns Hopkins University Press.

Hainmueller, Jens, Daniel J. Hopkins, and Teppei Yamamoto. 2014. Causal Inference in Conjoint Analysis: Understanding Multidimensional Choices via Stated Preference Experiments. Political Analysis 22(1): 1-30.

Huber, Gregory A., Seth J. Hill, and Gabriel S. Lenz. 2012. Sources of Bias in Retrospective Decision Making: Experimental Evidence on Voters' Limitations in Controlling Incumbents. American Political Science Review 106(4): 720-741.

Jost, John T., Christopher M. Federico, and Jaime L. Napier. 2009. Political Ideology: Its Structure, Functions, and Elective Affinities. Annual Review of Psychology 60: 307-37. 
Jost, John T., Jack Glaser, Arie W. Kruglanski, and Frank J. Sulloway. 2003. Political Conservatism as Motivated Social Cognition. Psychological Bulletin 129(3): 339-375.

Karr, Mia C. Apr. 6, 2017. University to Change 'Fair Harvard' Lyrics. Harvard Crimson. Available at: http://www.thecrimson.com/article/2017/4/6/fair-harvard-lyrics-change/

Krupnikov, Yanna and Adam Seth Levine. 2014. Cross-Sample Comparisons and External Validity. Journal of Experimental Political Science 1(1): 59-80.

Langbert, Mitchell, Anthony J. Quain, and Daniel B. Klein. 2016. Faculty Voter Registration in Economics, History, Journalism, Law, and Psychology. Econ Journal Watch 13(3): 422-451.

Laustsen, Lasse. 2017. Choosing the Right Candidate: Observational and Experimental Evidence that Conservatives and Liberals Prefer Powerful and Warm Candidate Personalities, Respectively. Political Behavior 39(4): 883-908.

Laustsen, Lasse and Alexander Bor. 2017. The Relative Weight of Character Traits in Political Candidate Evaluations: Warmth is More Important than Competence, Leadership and Integrity. Electoral Studies 49: 96-107.

Laverghetta, Antonio, Juliana Stewart, and Lawrence Weinstein. 2007. Anti-Intellectualism and Political Ideology in a Sample of Undergraduate and Graduate Students. Psychological Reports 101(3): 1050-1056.

Lenz, Gabriel S. and Chappell Lawson. 2011. Looking the Part: Television Leads Less Informed Citizens to Vote Based on Candidates' Appearance. American Journal of Political Science 55(3): $574-589$.

Lewis, Matt K. 2016. Too Dumb to Fail: How the GOP Went from the Party of Reagan to the Party of Trump. New York: Hachette Book Group.

Maranto, Robert, Richard E. Redding, and Frederick M. Hess, eds. 2009. The Politically Correct University: Problems, Scope, and Reforms. Washington, D.C.: AEI Press.

Mason, Winter and Duncan J. Watts. 2010. Financial Incentives and the Performance of Crowds. ACM SigKDD Explorations Newsletter 11(2): 100-108.

McAllister, Ian. 2007. The Personalization of Politics. In The Oxford Handbook of Political Behavior, eds. Russell J. Dalton and Hans-Dieter Klingemann. Oxford: Oxford University Press.

McDermott, Monika L. 2005. Candidate Occupations and Voter Information Shortcuts. Journal of Politics 67(1): 201-219.

McGraw, Kathleen M. 2011. Candidate Impressions and Evaluations. In Cambridge Handbook 
of Experimental Political Science, eds. James N. Druckman, Donald P. Green, James H. Kuklinski, and Arthur Lupia. Cambridge: Cambridge University Press.

Minta, Michael D. and Valeria Sinclair-Chapman. 2013. Diversity in Political Institutions and Congressional Responsiveness to Minority Interests. Political Research Quarterly 66(1): 127-140.

Mooney, Chris. 2005. The Republican War on Science. New York: Basic Books.

Motta, Matthew. 2018. The Dynamics and Political Implications of Anti-Intellectualism in the United States. American Politics Research 46(3): 465-498.

Ohr, Dieter and Henrik Oscarsson. 2013. Leader Traits, Leader Image, and Vote Choice. In Political Leaders and Democratic Elections, eds. Kees Aarts, Andre Blais, and Hermann Schmitt. Oxford: Oxford University Press.

Popkin, Samuel L. 1991. The Reasoning Voter: Communication and Persuasion in Presidential Campaigns. Chicago: University of Chicago Press.

Rapoport, Ronald B., Kelly L. Metcalf, and Jon A. Hartman. 1989. Candidate Traits and Voter Inferences: An Experimental Study. Journal of Politics 51(4): 917-932.

Rathbun, Brian C. 2007. Hierarchy and Community at Home and Abroad: Evidence of a Common Structure of Domestic and Foreign Policy Beliefs in American Elites. Journal of Conflict Resolution 51(3): 379-407.

Sigelman, Lee and Carol K. Sigelman. 1982. Sexism, Racism, and Ageism in Voting Behavior: An Experimental Analysis. Social Psychology Quarterly 45(4): 263-269.

Sanbonmatsu, Kira. 2002. Gender Stereotypes and Vote Choice. American Journal of Political Science 46(1): 20-34.

Shogan, Colleen J. 2007. Anti-Intellectualism in the Modern Presidency: A Republican Populism. Perspectives on Politics 5(2): 295-303.

Simon, Herbert A. 1956. Rational Choice and the Structure of the Environment. Psychological Review 63(2): 129-138.

Sowell, Thomas. 2009. Intellectuals and Society. New York: Basic Books.

Stack, Liam. Nov. 8, 2015. Yale's Halloween Advice Stokes a Racially Charged Debate. New York Times. Available at:

https://www.nytimes.com/2015/11/09/nyregion/yale-culturally-insensitive-halloween-costumes-f ree-speech.html 
Steel, Brent S. and Erika Allen Wolters. 2018. When Ideology Trumps Science: Why We Question the Experts on Everything from Climate Change to Vaccinations. Santa Barbara, CA: Praeger.

Strauss, Valerie. May 31, 2014. Bloomberg, at Harvard, Blasts Ivy League 'liberals' for 'trying to repress conservative ideas.' Washington Post. Available at:

https://www.washingtonpost.com/news/answer-sheet/wp/2014/05/31/bloomberg-at-harvard-blast s-ivy-league-liberals-for-trying-to-repress-conservative-ideas/?utm_term $=.998492 \mathrm{fa} 5 \mathrm{~b} 2 \mathrm{~d}$

Terkildsen, Nayda. 1993. When White Voters Evaluate Black Candidates: The Processing Implications of Candidate Skin Color, Prejudice, and Self-Monitoring. American Journal of Political Science 37(4): 1032-1053.

Tversky, Amos and Daniel Kahneman. 1974. Judgment Under Uncertainty: Heuristics and Biases. Science 185: 1124-31.

Wuest, Reto and Jonas Pontusson. 2018. Descriptive Misrepresentation by Social Class: Do Voter Preferences Matter? Presented at the 2018 Swiss Political Science Association Annual Conference.

Wattenberg, Martin P. 1991. The Rise of Candidate-Centered Politics: Presidential Elections of the 1980s. Cambridge, MA: Harvard University Press.

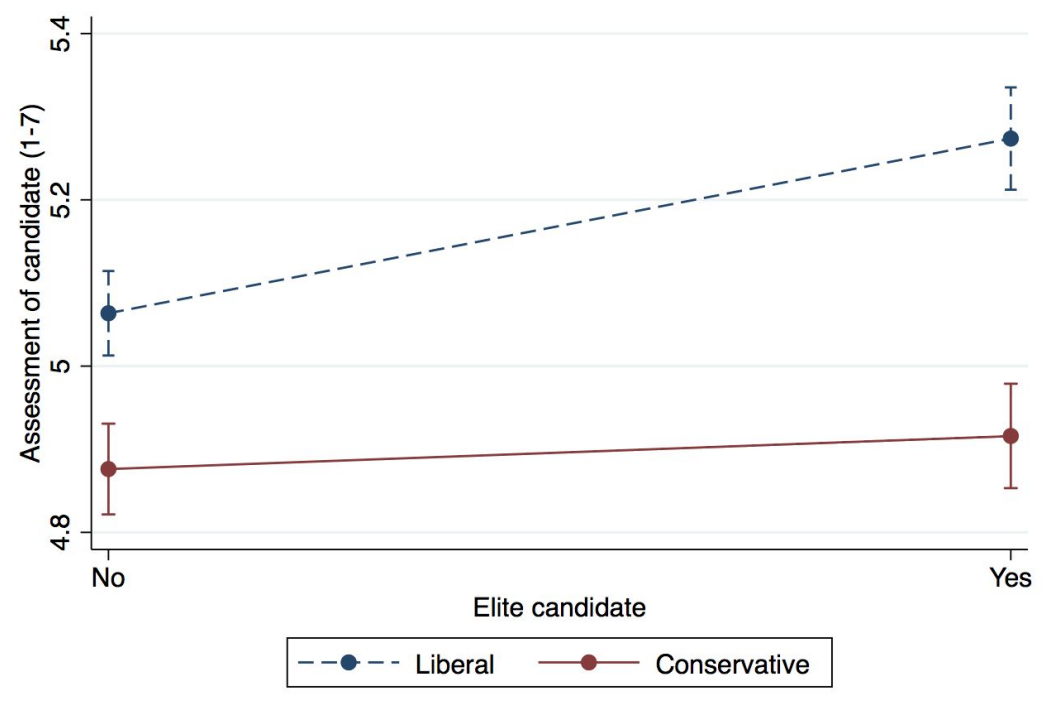

Figure 1 - Competence: Plots the effect of eliteness on perceived competence by showing predicted values by ideology of the respondent, at average values of the covariates and $95 \%$ 
confidence intervals of the point estimates.

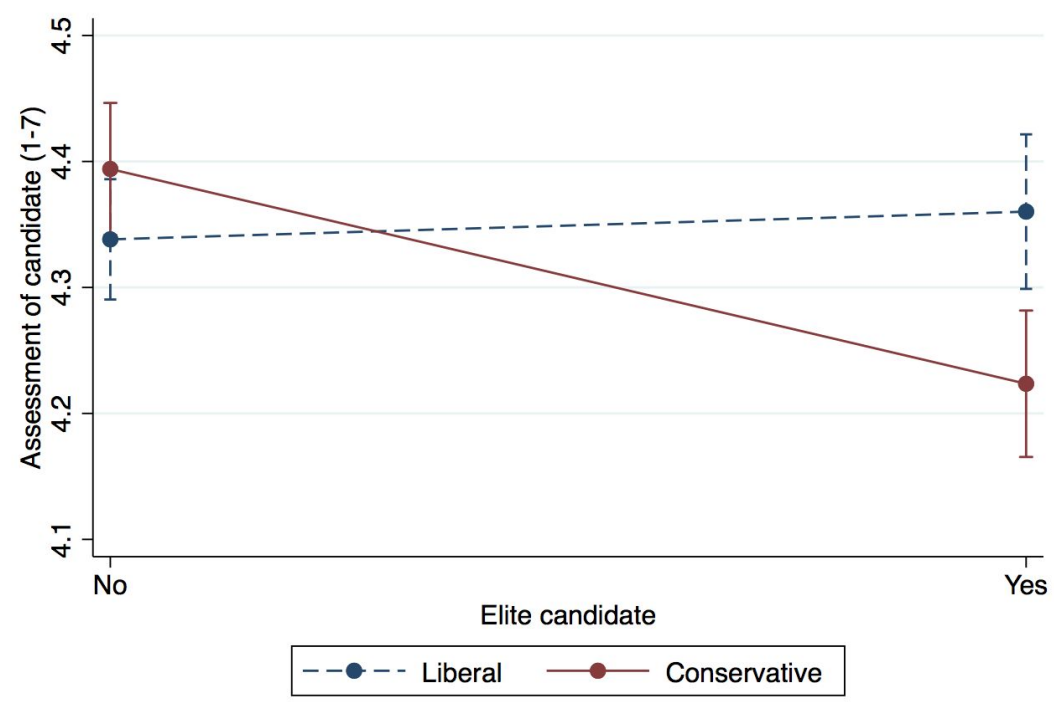

Figure 2 - Relatability: Plots the effect of eliteness on perceived relatability by showing predicted values by ideology of the respondent, at average values of the covariates and $95 \%$ confidence intervals of the point estimates.

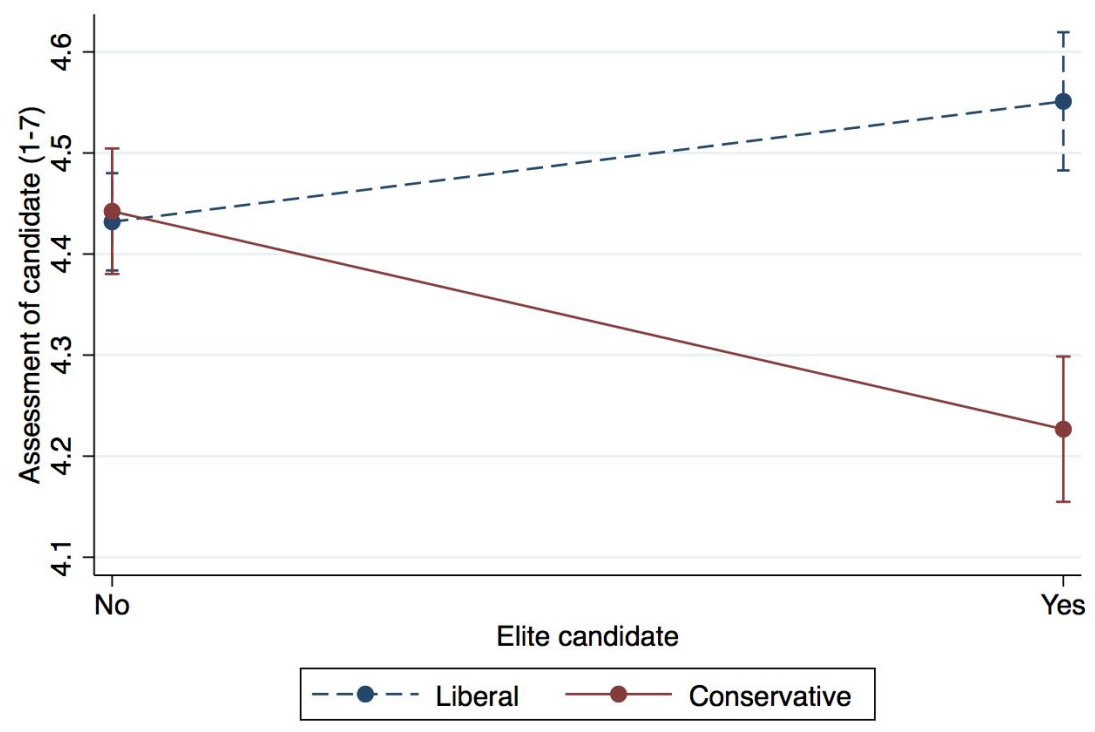

Figure 3 - Ballot Box Appeal: Plots the effect of eliteness on ballot box appeal by showing 
predicted values by ideology of the respondent, at average values of the covariates and $95 \%$ confidence intervals of the point estimates.
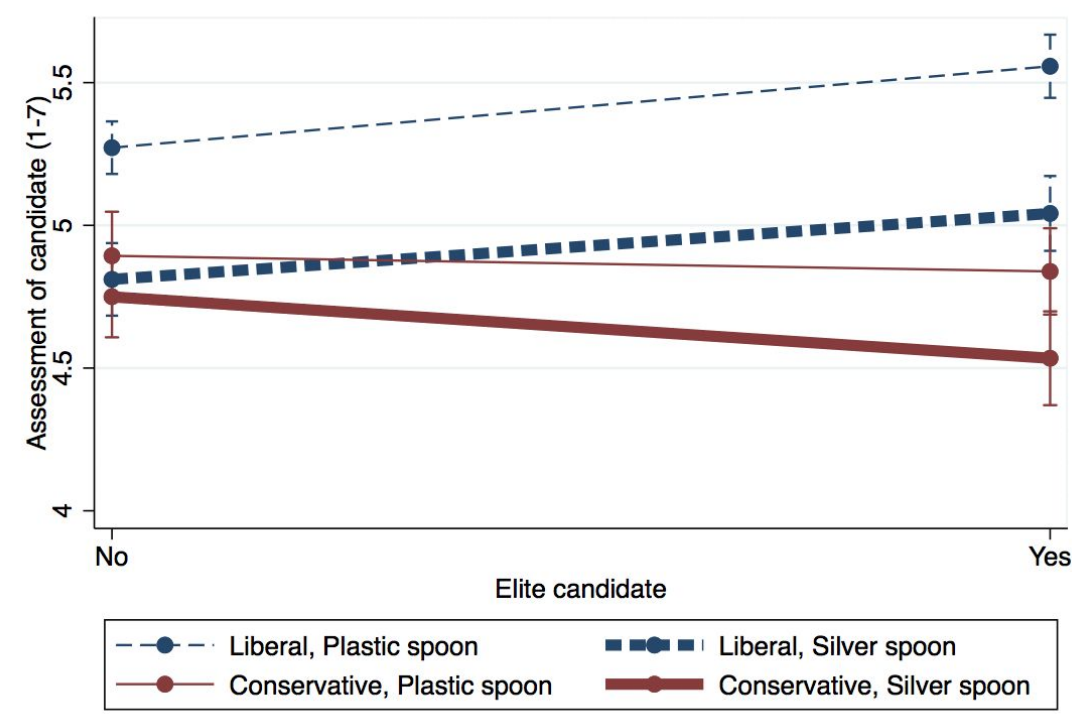

a: Competence

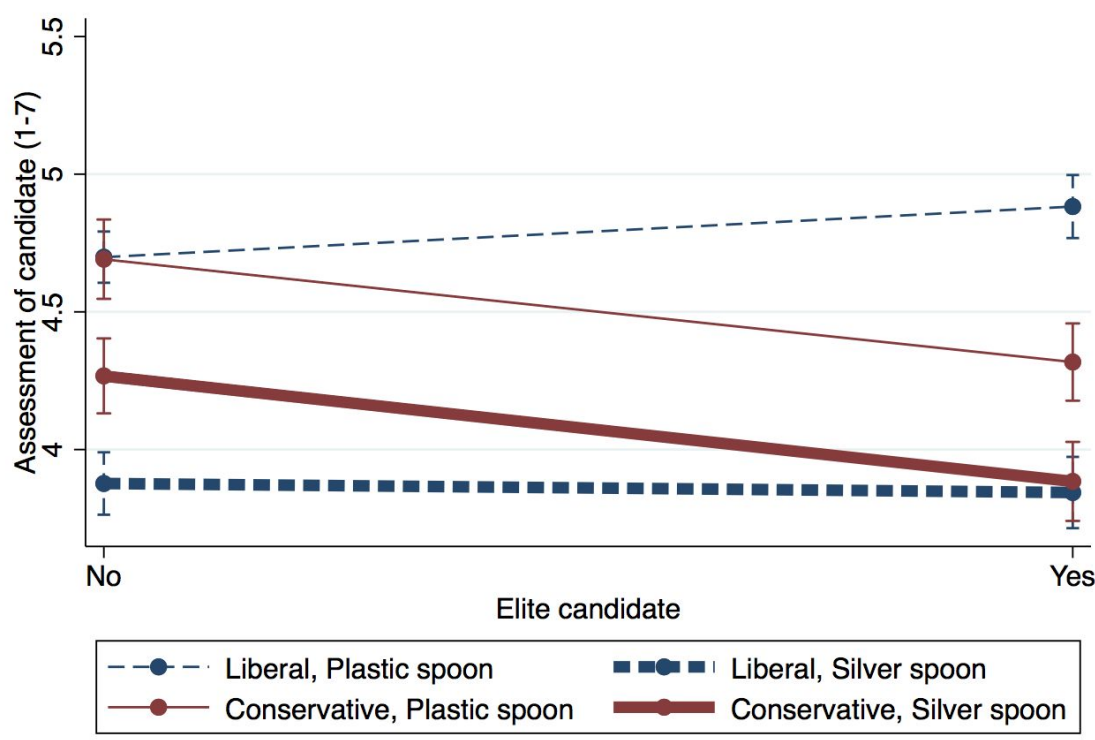

b: Relatability 


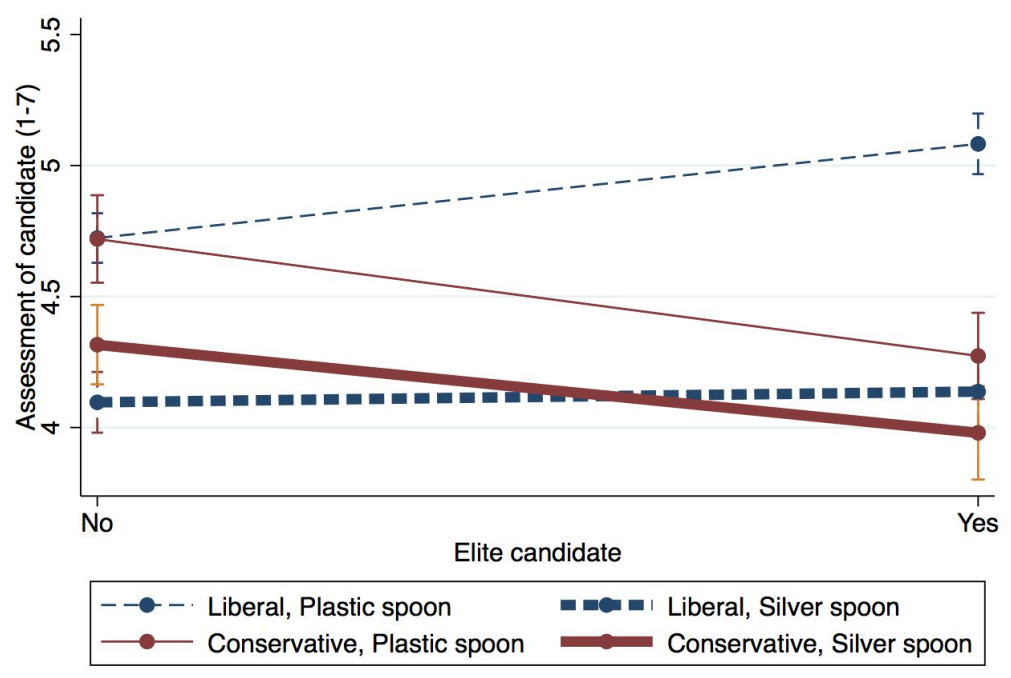

c: Ballot box appeal

Figure 4: Plots the effect of eliteness and spoon type on perceived competence (4a), perceived relatability (4b) and ballot box appeal (4c) by showing predicted values by ideology of the respondent, at average values of the covariates and 95\% confidence intervals of the point estimates. 


\section{Tables}

Table 1: Average effects of eliteness of the candidate

\begin{tabular}{lccc}
\hline \hline & $(1)$ & $(2)$ & $(3)$ \\
& Competence & Relatability & Ballot box appeal \\
\hline Elite & 0.109 & -0.0948 & -0.0600 \\
& $(0.0739)$ & $(0.0722)$ & $(0.0804)$ \\
No info & -0.0773 & -0.126 & -0.141 \\
& $(0.0959)$ & $(0.0935)$ & $(0.106)$ \\
Constant & $4.544^{* * *}$ & $3.808^{* * *}$ & $3.869^{* * *}$ \\
& $(0.161)$ & $(0.163)$ & $(0.171)$ \\
\hline Observations & 1227 & 1225 & 1221 \\
$R^{2}$ & 0.041 & 0.030 & 0.034 \\
\hline \hline & Each column reports coefficients from a linear model on US respondents using covari- \\
ates, as specified in the main text. Dependent variable is candidate rating on $1-7$ Likert \\
scale. Robust standard errors in parentheses. $* \mathrm{p}<0.05, * * \mathrm{p}<0.01, * * * \mathrm{p}<0.001$
\end{tabular}

Table 2: Average effects of eliteness of the candidate, by respondent ideology

\begin{tabular}{lccc}
\hline \hline & $(1)$ & $(2)$ & $(3)$ \\
& Competence & Relatability & Ballot box appeal \\
\hline Conservative X Elite & -0.248 & $-0.283^{*}$ & $-0.397^{*}$ \\
& $(0.150)$ & $(0.141)$ & $(0.164)$ \\
Elite & $0.223^{*}$ & 0.0251 & 0.103 \\
& $(0.103)$ & $(0.102)$ & $(0.107)$ \\
Conservative X No info & -0.301 & $-0.525^{* *}$ & $-0.430^{*}$ \\
& $(0.192)$ & $(0.186)$ & $(0.213)$ \\
No info & 0.0786 & 0.141 & 0.0782 \\
& $(0.130)$ & $(0.134)$ & $(0.135)$ \\
Conservative & -0.144 & 0.109 & 0.0435 \\
& $(0.133)$ & $(0.126)$ & $(0.135)$ \\
Constant & & & \\
& $4.462^{* * *}$ & $3.711^{* * *}$ & $3.744^{* * *}$ \\
\hline Observations & $(0.165)$ & $(0.165)$ & $(0.175)$ \\
$R^{2}$ & 1193 & 1191 & 1187 \\
\hline \hline
\end{tabular}

Each column reports coefficients from a linear model on US respondents using covariates, as specified in the main text. Dependent variable is candidate rating on 1-7 Likert scale. Robust standard errors in parentheses. $* \mathrm{p}<0.05, * * \mathrm{p}<0.01, * * * \mathrm{p}<0.001$ 
Table 3: Average effects of eliteness and economic background of the candidate, by respondent ideology

\begin{tabular}{lccc}
\hline \hline & $(1)$ & $(2)$ & $(3)$ \\
& Competence & Relatability & Ballot box appeal \\
\hline Conservative X Elite X Silver spoon & -0.0581 & 0.264 & 0.434 \\
& $(0.378)$ & $(0.359)$ & $(0.409)$ \\
Elite X Silver spoon & -0.0426 & -0.240 & -0.325 \\
& $(0.264)$ & $(0.255)$ & $(0.265)$ \\
Conservative X Elite & -0.368 & $-0.560^{*}$ & $-0.798^{* *}$ \\
& $(0.239)$ & $(0.243)$ & $(0.268)$ \\
Conservative X Silver spoon & 0.358 & 0.400 & 0.250 \\
& $(0.255)$ & $(0.241)$ & $(0.259)$ \\
Silver spoon & $-0.529^{* *}$ & $-0.840^{* * *}$ & $-0.673^{* * *}$ \\
& $(0.182)$ & $(0.166)$ & $(0.164)$ \\
Conservative & $-0.418^{*}$ & -0.141 & -0.153 \\
& $(0.205)$ & $(0.190)$ & $(0.211)$ \\
Elite & & & $0.339^{*}$ \\
$R^{2}$ & 0.272 & 0.176 & $(0.167)$ \\
\hline \hline Constant & $(0.164)$ & $(0.168)$ & $4.093^{* * *}$ \\
& & & $(0.260)$ \\
\hline
\end{tabular}

Each column reports coefficients from a linear model on US respondents using covariates, as specified in the main text. Only includes respondents who received a candidate education and economic background prime (T3-T6) Dependent variable is candidate rating on 1-7 Likert scale. Robust standard errors in parentheses. $* \mathrm{p}<0.05$, $* *$ $\mathrm{p}<0.01, * * * \mathrm{p}<0.001$ 


\section{Appendix Tables}

\section{Appendix A: Extensions}

Table A1: Summary characteristics of US-based survey respondents

\begin{tabular}{lccc|ccc}
\hline \hline \multicolumn{1}{c|}{ Vhole sample } & \multicolumn{3}{c}{ Respondents to all key questions } \\
\hline Female & Mean & Std. Dev. & $\mathrm{N}$ & Mean & Std. Dev. & $\mathrm{N}$ \\
Nonwhite & 0.48 & 0.5 & 1264 & 0.47 & 0.5 & 1169 \\
Hispanic & 0.09 & 0.29 & 1316 & 0.09 & 0.29 & 1215 \\
Age & 0.04 & 0.19 & 1290 & 0.04 & 0.19 & 1197 \\
College graduate & 41.92 & 12.41 & 1110 & 42.22 & 12.33 & 1027 \\
Annual income & 6.72 & 0.45 & 1316 & 0.73 & 0.44 & 1215 \\
Conservative & 0.48 & 48631 & 1216 & 62286 & 49160 & 1124 \\
Republican & 0.30 & 0.46 & 1272 & 0.48 & 0.5 & 1181 \\
Other party & 0.31 & 0.46 & 1240 & 0.31 & 0.46 & 1146 \\
\hline \hline
\end{tabular}

The number of observations is approximately twice the number of unique respondents, as each respondent answered questions about two hypothetical candidates. For each variable, shows statistics for US respondents and non-imputed values only. Key questions pertain to competence, relatability, and ballot box appeal. 
Table A2: Correlations between key dependent variables

\begin{tabular}{lccc} 
& Competence & Relatability & Ballot box appeal \\
\hline Competence & 1 & & \\
Relatability & $0.631^{* * *}$ & 1 & \\
Ballot box appeal & $0.632^{* * *}$ & $0.790^{* * *}$ & 1 \\
\hline \hline${ }^{*} p<0.05,^{* *} p<0.01,{ }^{* * *} p<0.001$ & &
\end{tabular}


Table A3: Average effects of eliteness of the candidate on individual relatability measures, by respondent ideology

\begin{tabular}{|c|c|c|c|c|}
\hline & $\begin{array}{c}(1) \\
\text { Relatability }\end{array}$ & \begin{tabular}{l}
\multicolumn{1}{c}{$(2)$} \\
Fight for people \\
like me
\end{tabular} & $\begin{array}{l}\text { Fun to spend time } \\
\text { with }\end{array}$ & \begin{tabular}{l}
\multicolumn{1}{c}{$(4)$} \\
Understand my \\
concerns
\end{tabular} \\
\hline Conservative X Elite & $\begin{array}{l}-0.283^{*} \\
(0.141)\end{array}$ & $\begin{array}{l}-0.215 \\
(0.170)\end{array}$ & $\begin{array}{l}-0.392^{*} \\
(0.156)\end{array}$ & $\begin{array}{l}-0.258 \\
(0.174)\end{array}$ \\
\hline Elite & $\begin{array}{l}0.0251 \\
(0.102)\end{array}$ & $\begin{array}{r}-0.0460 \\
(0.121)\end{array}$ & $\begin{array}{l}0.0885 \\
(0.105)\end{array}$ & $\begin{array}{l}0.0399 \\
(0.121)\end{array}$ \\
\hline Conservative $\mathrm{X}$ No info & $\begin{array}{c}-0.525^{* *} \\
(0.186)\end{array}$ & $\begin{array}{l}-0.535^{*} \\
(0.215)\end{array}$ & $\begin{array}{l}-0.473^{*} \\
(0.197)\end{array}$ & $\begin{array}{l}-0.559^{*} \\
(0.230)\end{array}$ \\
\hline No info & $\begin{array}{c}0.141 \\
(0.134)\end{array}$ & $\begin{array}{c}0.150 \\
(0.154)\end{array}$ & $\begin{array}{c}0.105 \\
(0.131)\end{array}$ & $\begin{array}{c}0.159 \\
(0.166)\end{array}$ \\
\hline Conservative & $\begin{array}{c}0.109 \\
(0.126)\end{array}$ & $\begin{array}{c}-0.0489 \\
(0.142)\end{array}$ & $\begin{array}{l}0.353^{*} \\
(0.139)\end{array}$ & $\begin{array}{l}0.0152 \\
(0.150)\end{array}$ \\
\hline Constant & $\begin{array}{c}3.711^{* * *} \\
(0.165)\end{array}$ & $\begin{array}{c}3.908^{* * *} \\
(0.195)\end{array}$ & $\begin{array}{c}3.635^{* * *} \\
(0.165)\end{array}$ & $\begin{array}{c}3.607^{* * *} \\
(0.194)\end{array}$ \\
\hline $\begin{array}{l}\text { Observations } \\
R^{2}\end{array}$ & $\begin{array}{l}1191 \\
0.037\end{array}$ & $\begin{array}{l}1196 \\
0.042\end{array}$ & $\begin{array}{l}1193 \\
0.025\end{array}$ & $\begin{array}{l}1194 \\
0.039\end{array}$ \\
\hline
\end{tabular}

Each column reports coefficients from a linear model on US respondents using covariates, as specified in the main text. Model 1 replicates Model 2 of Table 2. Dependent variable is candidate rating on 1-7 Likert scale. Robust standard errors in parentheses. $* \mathrm{p}<0.05, * * \mathrm{p}<0.01, * * * \mathrm{p}<0.001$ 
Table A4: Average effects of eliteness of the candidate, by respondent ideology, contrasting respondents who receive the elite treatment and those who receive no information on the educational background of the candidate

\begin{tabular}{lccc}
\hline \hline & $(1)$ & $(2)$ & $(3)$ \\
& Competence & Relatability & Ballot box appeal \\
\hline Conservative X Elite & 0.0734 & 0.181 & -0.00361 \\
& $(0.198)$ & $(0.186)$ & $(0.221)$ \\
Elite & 0.114 & -0.129 & 0.0413 \\
& $(0.142)$ & $(0.141)$ & $(0.140)$ \\
Conservative X Non-elite & 0.259 & $0.364^{*}$ & 0.315 \\
& $(0.197)$ & $(0.185)$ & $(0.215)$ \\
Non-elite & -0.0776 & -0.117 & -0.0259 \\
& $(0.140)$ & $(0.135)$ & $(0.129)$ \\
Conservative & & -0.347 & -0.313 \\
& $-0.459^{*}$ & $(0.178)$ & $(0.205)$ \\
Constant & $(0.186)$ & & \\
& & & \\
& $4.505^{* * *}$ & $3.785^{* * *}$ & $3.808^{* * *}$ \\
\hline Observations & $(0.186)$ & $(0.186)$ & $(0.198)$ \\
$R^{2}$ & 1193 & 1191 & 1187 \\
\hline \hline Each column reports coefficients from a linear model on US respondents using covariates, as \\
specified in the main text. Dependent variable is candidate rating on 1-7 Likert scale. Robust \\
standard errors in parentheses. * $<<0.05, * *$ p $<0.01, * * *$ p $<0.001$ &
\end{tabular}


Table A5: Average effects for each of the three universities in the elite treatment, by respondent ideology

\begin{tabular}{lccc}
\hline \hline & $(1)$ & $(2)$ & $(3)$ \\
& Competence & Relatability & Ballot box appeal \\
\hline Conservative X Harvard & -0.190 & -0.343 & -0.475 \\
& $(0.215)$ & $(0.214)$ & $(0.247)$ \\
Harvard & 0.193 & 0.0175 & 0.0475 \\
& $(0.149)$ & $(0.151)$ & $(0.169)$ \\
\hline Observations & 800 & 800 & 797 \\
\hline \hline Conservative X Yale & $-0.496^{*}$ & -0.359 & $-0.610^{*}$ \\
& $(0.220)$ & $(0.218)$ & $(0.253)$ \\
Yale & 0.273 & -0.0248 & 0.0897 \\
& $(0.139)$ & $(0.155)$ & $(0.167)$ \\
\hline Observations & 808 & 806 & 803 \\
\hline \hline Conservative X Princeton & -0.176 & -0.268 & -0.323 \\
& $(0.218)$ & $(0.210)$ & $(0.230)$ \\
Princeton & & & 0.143 \\
& 0.162 & 0.0188 & $(0.158)$ \\
\hline Observations & $(0.161)$ & $(0.152)$ & 795 \\
\hline \hline
\end{tabular}

Each panel reports coefficients from three linear models on US respondents. Dependent variable is candidate rating on 1-7 Likert scale. Models in each panel include, in addition to the school variables shown, an indicator for the no information treatment (the omitted category is liberals assigned to the nonelite treatment). The models are restricted to those receiving the school of focus prime, nonelite schools, and those receiving no information; they exclude respondents receiving the other two elite primes. The models also include individual covariates, as specified in the main text. Robust standard errors in parentheses. $* \mathrm{p}<0.05, * * \mathrm{p}<0.01, * * * \mathrm{p}<0.001$ 
Table A6: Average effects for each of the three universities in the non-elite treatment, by respondent ideology

\begin{tabular}{lccc}
\hline \hline & $(1)$ & $(2)$ & $(3)$ \\
& Competence & Relatability & Ballot box appeal \\
\hline Conservative X Lehigh & 0.157 & 0.117 & 0.248 \\
& $(0.190)$ & $(0.196)$ & $(0.220)$ \\
Lehigh & -0.137 & 0.00620 & -0.0225 \\
& $(0.132)$ & $(0.133)$ & $(0.142)$ \\
\hline Observations & 857 & 855 & 852 \\
\hline \hline Conservative X Northeastern & $0.372^{*}$ & 0.271 & $0.512^{* *}$ \\
& $(0.185)$ & $(0.172)$ & $(0.192)$ \\
Northeastern & & & -0.242 \\
& $-0.297^{*}$ & -0.0715 & $(0.125)$ \\
\hline Observations & $(0.129)$ & $(0.119)$ & 856 \\
\hline \hline Conservative X BU & 860 & 857 & 0.230 \\
& 0.273 & 0.303 & $(0.240)$ \\
BU & $(0.213)$ & $(0.225)$ & -0.0455 \\
& & & $(0.168)$ \\
\hline Observations & -0.289 & -0.172 & 785 \\
\hline \hline
\end{tabular}

Each panel reports coefficients from three linear models on US respondents. Dependent variable is candidate rating on 1-7 Likert scale. Models in each panel include, in addition to the school variables shown, an indicator for the no information treatment (the omitted category is liberals assigned to the elite treatment). The models are restricted to those receiving the school of focus prime, elite schools, and those receiving no information; they exclude respondents receiving the other two nonelite primes. The models also include individual covariates, as specified in the main text. Robust standard errors in parentheses. $* \mathrm{p}<0.05, * * \mathrm{p}<0.01, * * * \mathrm{p}<0.001$ 
Table A7: Average effects of eliteness of the candidate, by respondent ideology, controlling for perceived partisanship of the candidate

\begin{tabular}{lccc}
\hline \hline & $\begin{array}{c}(1) \\
\text { Competence }\end{array}$ & $\begin{array}{c}(2) \\
\text { Relatability }\end{array}$ & $\begin{array}{c}(3) \\
\text { Ballot box appeal }\end{array}$ \\
\hline Conservative X Elite & -0.254 & $-0.294^{*}$ & $-0.411^{*}$ \\
& $(0.148)$ & $(0.142)$ & $(0.161)$ \\
Elite & $0.229^{*}$ & 0.0370 & 0.117 \\
& $(0.102)$ & $(0.0947)$ & $(0.102)$ \\
Conservative X No info & -0.298 & $-0.538^{* *}$ & $-0.439^{*}$ \\
& $(0.191)$ & $(0.185)$ & $(0.213)$ \\
No info & 0.117 & 0.189 & 0.133 \\
& $(0.140)$ & $(0.137)$ & $(0.142)$ \\
Conservative & -0.135 & 0.125 & 0.0606 \\
& $(0.132)$ & $(0.122)$ & $(0.133)$ \\
Republican candidate & & & $-0.213^{*}$ \\
& 0.0774 & $-0.243^{*}$ & $(0.107)$ \\
Missing candidate partisanship & $(0.0993)$ & $(0.0945)$ & -0.0779 \\
& $0.233^{*}$ & -0.140 & $(0.103)$ \\
\hline Observations & $(0.0947)$ & $(0.0926)$ & 1187 \\
$R^{2}$ & 1193 & 1191 & 0.073 \\
\hline \hline Each column reports coefficients from a linear model on US respondents using covariates, as specified in the \\
main text. Dependent variable is candidate rating on 1-7 Likert scale. Robust standard errors in parentheses. \\
$*$ p $<0.05$, ** p<0.01, *** p<0.001 \\
& & &
\end{tabular}




\section{Appendix B: Alternative specifications: linear models with no controls and ordered probit models}

Table B1: Average effects of eliteness of the candidate, by respondent ideology. Linear models with no controls

\begin{tabular}{lccc}
\hline \hline & $(1)$ & $(2)$ & $(3)$ \\
& Competence & Relatability & Ballot box appeal \\
\hline Conservative X Elite & -0.238 & $-0.318^{*}$ & $-0.435^{* *}$ \\
& $(0.149)$ & $(0.146)$ & $(0.164)$ \\
Elite & $0.224^{*}$ & 0.0514 & 0.137 \\
& $(0.103)$ & $(0.104)$ & $(0.109)$ \\
Conservative X No info & -0.271 & $-0.503^{* *}$ & -0.403 \\
& $(0.191)$ & $(0.184)$ & $(0.214)$ \\
No info & 0.0656 & 0.151 & 0.0971 \\
& $(0.128)$ & $(0.133)$ & $(0.137)$ \\
Conservative & -0.119 & 0.181 & 0.112 \\
& $(0.105)$ & $(0.102)$ & $(0.111)$ \\
Constant & & & \\
& $5.031^{* * *}$ & $4.241^{* * *}$ & $4.349^{* * *}$ \\
\hline Observations & $(0.0801)$ & $(0.0785)$ & $(0.0800)$ \\
$R^{2}$ & 1255 & 1253 & 1249 \\
\hline \hline
\end{tabular}

Each column reports coefficients from a linear model on US respondents without covariates. Dependent variable is candidate rating on 1-7 Likert scale. Robust standard errors in parentheses. ${ }^{*} \mathrm{p}<0.05$, $* * \mathrm{p}<0.01, * * * \mathrm{p}<0.001$ 
Table B2: Average effects of eliteness of the candidate, by respondent ideology. Ordered probit models with demographic controls

\begin{tabular}{|c|c|c|c|}
\hline & $\begin{array}{c}(1) \\
\text { Competence }\end{array}$ & $\begin{array}{c}(2) \\
\text { Relatability }\end{array}$ & $\begin{array}{c}(3) \\
\text { Ballot box appeal }\end{array}$ \\
\hline Conservative X Elite & $\begin{array}{l}-0.249 \\
(0.134)\end{array}$ & $\begin{array}{l}-0.285^{*} \\
(0.128)\end{array}$ & $\begin{array}{l}-0.354^{* *} \\
(0.135)\end{array}$ \\
\hline Elite & $\begin{array}{c}0.228^{*} \\
(0.0937)\end{array}$ & $\begin{array}{c}0.0468 \\
(0.0895)\end{array}$ & $\begin{array}{c}0.115 \\
(0.0885)\end{array}$ \\
\hline Conservative $\mathrm{X}$ No info & $\begin{array}{l}-0.261 \\
(0.171)\end{array}$ & $\begin{array}{l}-0.488^{* *} \\
(0.168)\end{array}$ & $\begin{array}{l}-0.372^{*} \\
(0.179)\end{array}$ \\
\hline No info & $\begin{array}{l}0.0416 \\
(0.118)\end{array}$ & $\begin{array}{c}0.113 \\
(0.122)\end{array}$ & $\begin{array}{l}0.0577 \\
(0.116)\end{array}$ \\
\hline Conservative & $\begin{array}{l}-0.125 \\
(0.120)\end{array}$ & $\begin{array}{c}0.124 \\
(0.111)\end{array}$ & $\begin{array}{l}0.0686 \\
(0.113)\end{array}$ \\
\hline Observations & 1193 & 1191 & 1187 \\
\hline AIC & 3612.8 & 6104.0 & 3670.7 \\
\hline
\end{tabular}

